\title{
A Small Footprint and Robust Interface for Solid Phase Microextraction and Mass Spectrometry based on Vibrating Sharp- edge Spray Ionization
}

\author{
Jing Wang, ${ }^{\text {[a] }}$ Chong Li, ${ }^{\text {[a] }}$ Peng Li ${ }^{\star[a]}$
}

[a]. C. Eugene Bennett Department of Chemistry, West Virginia University, Morgantown, WV, USA.

*Correspondence should be addressed to P.L. (peng.li@mail.wvu.edu)

Table S1 - Low flow rates achieved by cVSSI

Table S2 - Recovery test for spiked samples

Table S3 - Data for all the calibration curves

Table S4 - Typical Therapeutic concentrations of drugs tested.

Figure $\mathrm{S} 1$ - Optimization of device distance to the mass spectrometer inlet

Figure S2 - Optimization of capillary angle to the mass spectrometer inlet

Figure S3 - A close up picture of the cVSSI-MS setup

Figure S4 - Comparison of mass spectra with different capillary temperature

Figure S5 - Comparison of mass spectra with different spray time

Figure S6 - Comparison of capillaries with $15 \mu \mathrm{m}$ and $50 \mu \mathrm{m}$ tip size

Figure S7 - Comparison of mass spectra obtained with glue seal and without glue

Figure S8 - Study of desorption time for $100 \mathrm{nM}$ samples

Figure S9 - A full range calibration curve of SPME-cVSSI-MS for metoprolol in serum

Figure S10 - A full range calibration curve of SPME-nESI-MS for metoprolol in serum

Figure S11 - Calibration curves for 4 different drug compounds from serum samples. 


\begin{tabular}{|c|c|c|c|}
\hline $\begin{array}{c}\text { Frequency } \\
(\mathbf{k H z})\end{array}$ & $\begin{array}{c}\text { Amplitude } \\
\left(\mathbf{V}_{\mathbf{p p}}\right)\end{array}$ & $\begin{array}{c}\text { Volume } \\
(\boldsymbol{\mu L})\end{array}$ & $\begin{array}{c}\text { Flow Rate } \\
(\boldsymbol{\mu L} / \mathbf{m i n})\end{array}$ \\
\hline 93 & 7 & 6 & $0.46 \pm 0.02$ \\
\hline 93 & 9 & 6 & $0.58 \pm 0.03$ \\
\hline 93 & 11 & 6 & $0.70 \pm 0.02$ \\
\hline
\end{tabular}

Table S1 Spray flow rates of the cVSSI for a $15 \mu \mathrm{m}$ pulled-tip capillary under different input voltage. 


\begin{tabular}{|c|c|c|c|}
\hline Analyte & $\begin{array}{c}\text { Spiked Concentration } \\
(\mathbf{n g} / \mathbf{m L})\end{array}$ & $\begin{array}{c}\text { Found Concentration } \\
(\mathbf{n g} / \mathbf{m L})\end{array}$ & $\begin{array}{c}(\%) \text { Recovery } \\
( \pm \mathbf{S D})\end{array}$ \\
\hline \multirow{4}{*}{ metoprolol } & 0.267 & $0.24( \pm 0.01)$ & $91( \pm 4)$ \\
\cline { 2 - 4 } & 6.675 & $5.54( \pm 0.20)$ & $83( \pm 3)$ \\
\cline { 2 - 4 } & 13.36 & $10.69( \pm 0.20)$ & $80( \pm 2)$ \\
\cline { 2 - 4 } & 20.25 & $17.62( \pm 0.91)$ & $87( \pm 5)$ \\
\cline { 2 - 4 } & 26.7 & $21.89( \pm 0.99)$ & $82( \pm 4)$ \\
\hline
\end{tabular}

Table S2 Recovery test for spiked metoprolol samples at different concentrations. 


\begin{tabular}{|l|l|l|l|}
\hline Analyte & $\begin{array}{l}\text { Dynamic Range } \\
(\mathbf{n g} / \mathrm{mL})\end{array}$ & Linear Curve & $\mathbf{R}^{2}$ \\
\hline Metoprolol & $0.267-26.7$ & $\mathrm{Y}=0.038 \mathrm{X}-0.007$ & 0.9968 \\
\hline Pindolol & $0.249-24.9$ & $\mathrm{Y}=0.006 \mathrm{X}+0.040$ & 0.9701 \\
\hline Irinotecan & $0.585-58.5$ & $\mathrm{Y}=0.016-0.045$ & 0.9856 \\
\hline Capecitabine & $0.360-36.0$ & $\mathrm{Y}=0.010 \mathrm{X}+0.082$ & 0.9918 \\
\hline Acebutolol & $0.337-33.7$ & $\mathrm{Y}=0.010 \mathrm{X}-0.040$ & 0.9920 \\
\hline Oxprenolol & $0.266-26.6$ & $\mathrm{Y}=0.010 \mathrm{X}+0.054$ & 0.9924 \\
\hline
\end{tabular}

Table S3 Calibration curves for all the compounds tested. 


\begin{tabular}{|c|c|c|c|}
\hline Analyte & $\begin{array}{c}\text { Therapeutic Concentration } \\
\text { (ng/mL) }\end{array}$ & $\begin{array}{c}\text { Limit of Detection } \\
\text { of the present } \\
\text { method } \\
\text { (ng/mL) }\end{array}$ & Reference \\
\hline Metoprolol & 14 to 212 & 0.27 & {$[1]$} \\
\hline Pindolol & 100 & 0.25 & {$[2]$} \\
\hline Irinotecan & 1600 & 0.59 & {$[3]$} \\
\hline Capecitabine & 2700 to 4000 & 0.36 & {$[4]$} \\
\hline Acebutolol & 200 to 2000 & 0.34 & {$[5]$} \\
\hline Oxprenolol & 680 & 0.27 & {$[6]$} \\
\hline
\end{tabular}

Table S4 Typical Therapeutic concentrations of drugs tested. 


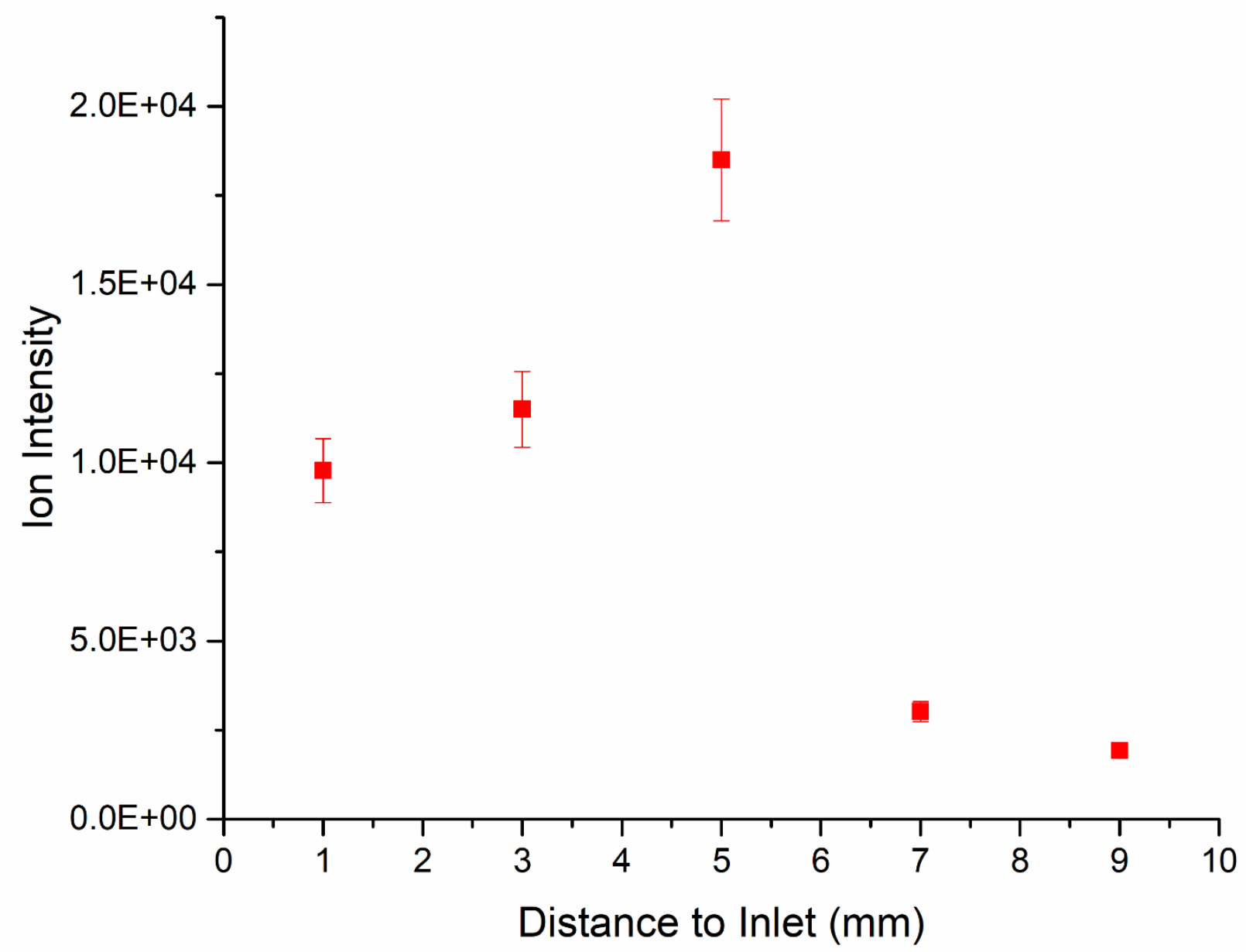

Figure S1: The relationship between ion intensity and the distance to the mass spectrometer inlet. The optimal distance to the inlet was determined to be $5 \mathrm{~mm}$. 


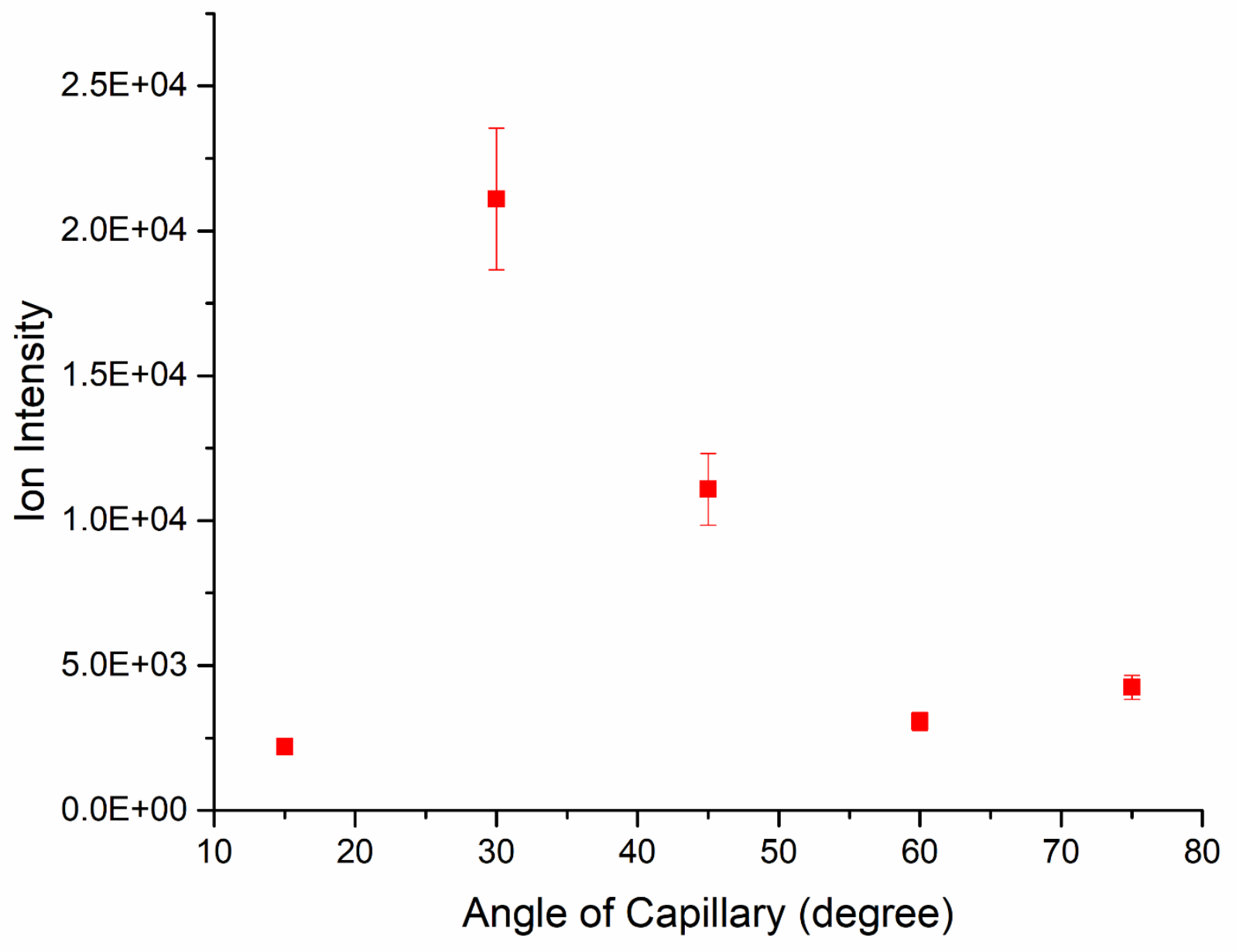

Figure S2: The relationship between ion intensity and the angle to the mass spectrometer inlet. The optimal distance to the inlet was determined to be 30 degree. 


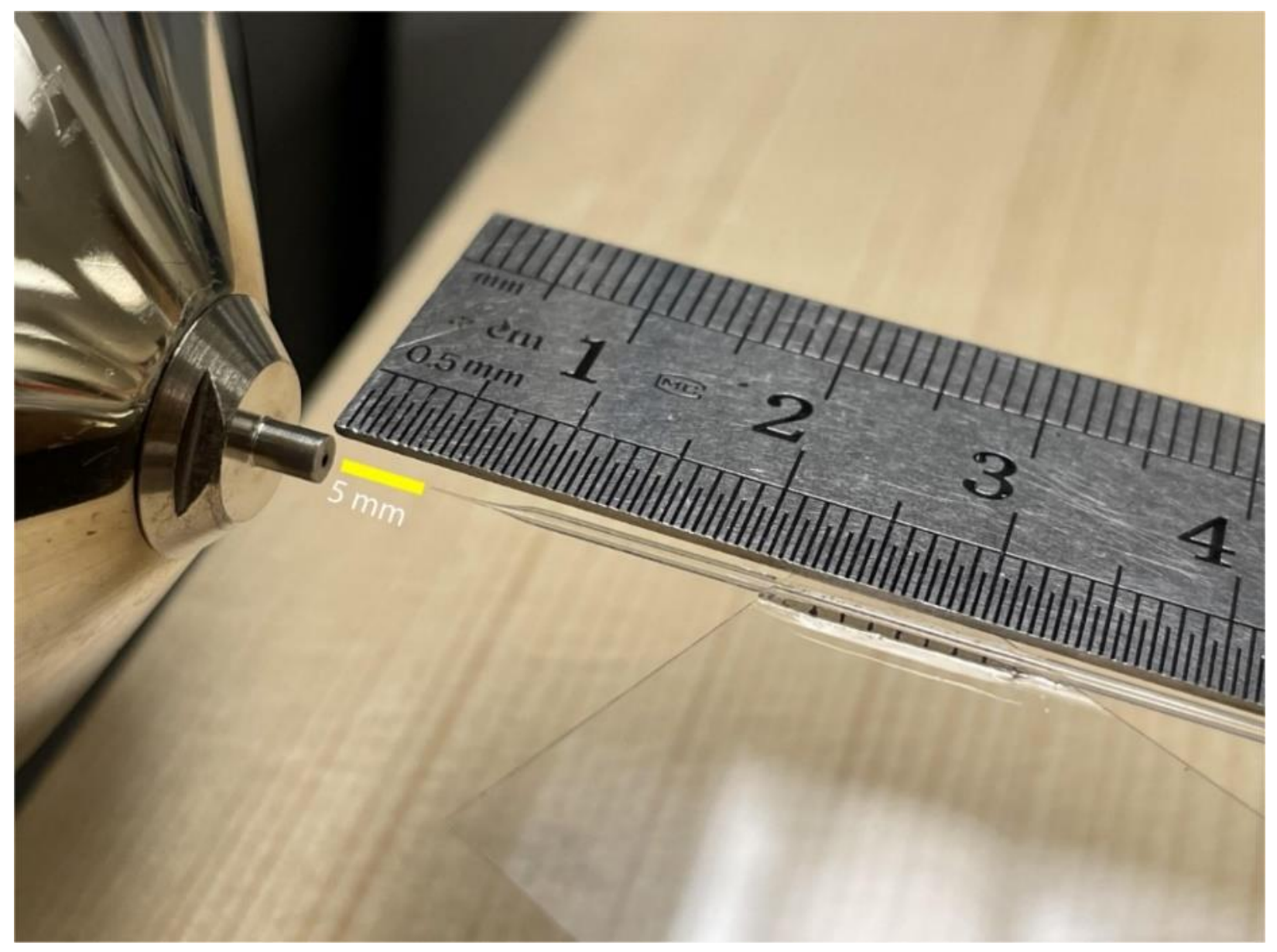

Figure S3 A close up picture of the cVSSI-MS setup 


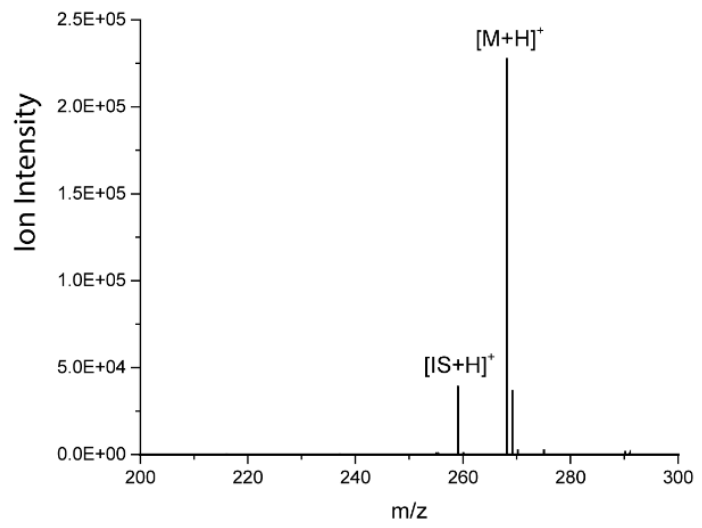

Capillary Temperature: $50 \mathrm{C}$

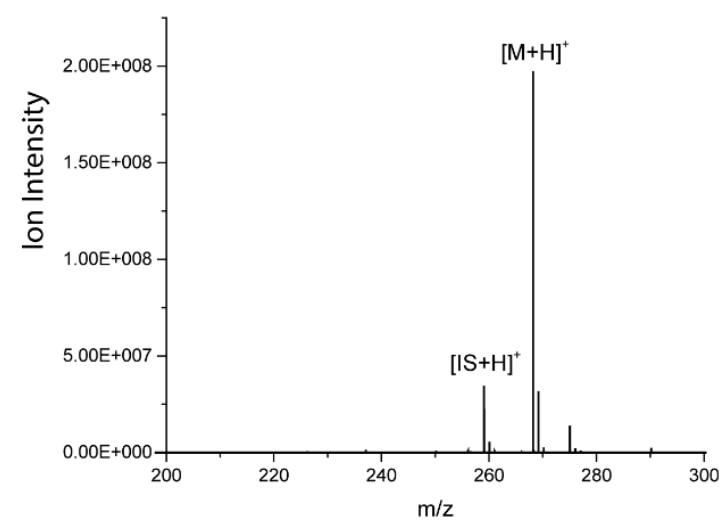

Capillary Temperature: $375{ }^{\circ} \mathrm{C}$

Figure S4 Comparison of mass spectra of $10 \mu \mathrm{M}$ metoprolol with different capillary temperatures. Left: $50{ }^{\circ} \mathrm{C}$; Right: $375^{\circ} \mathrm{C}$ 
a)

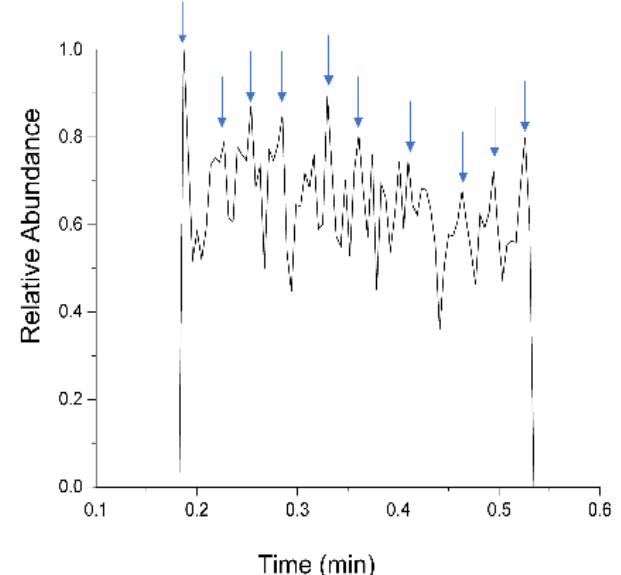

c)

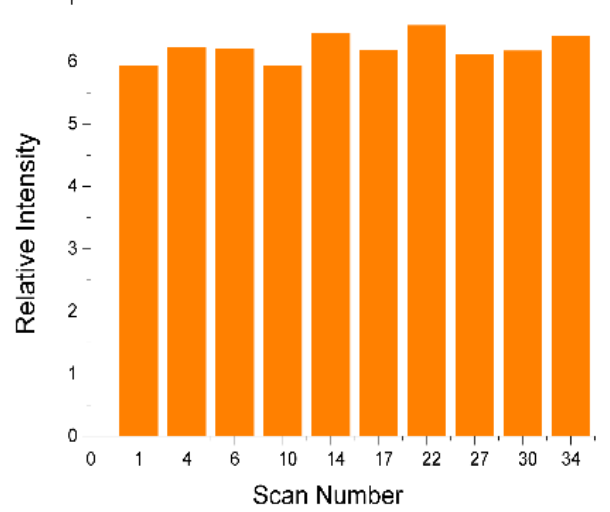

e)

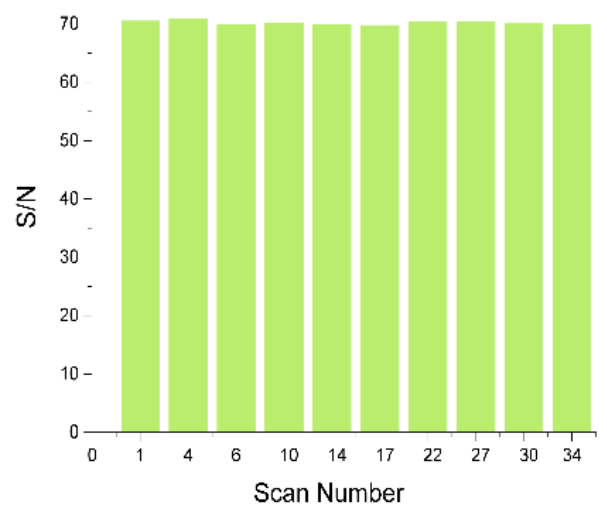

g)

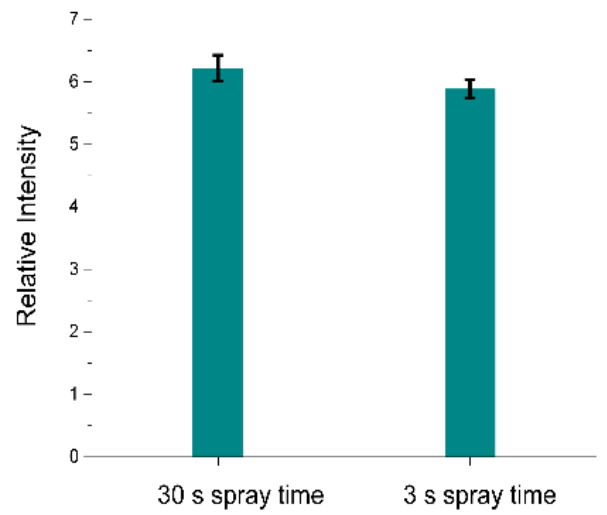

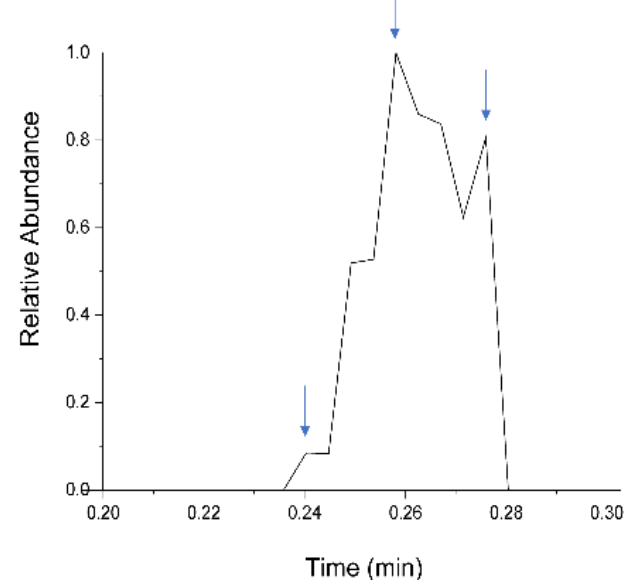

d)

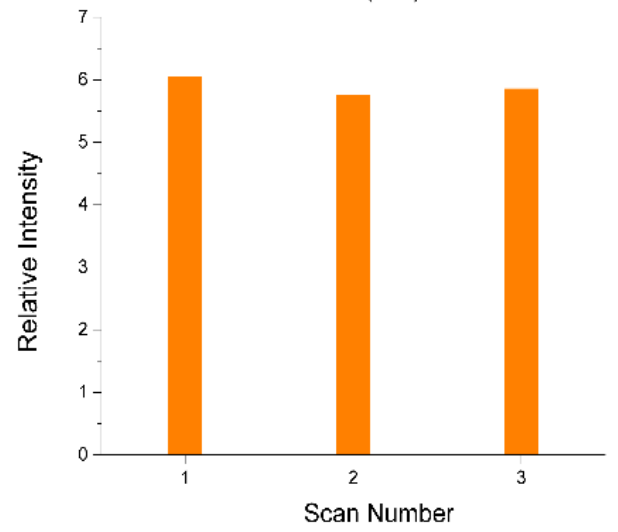

f)

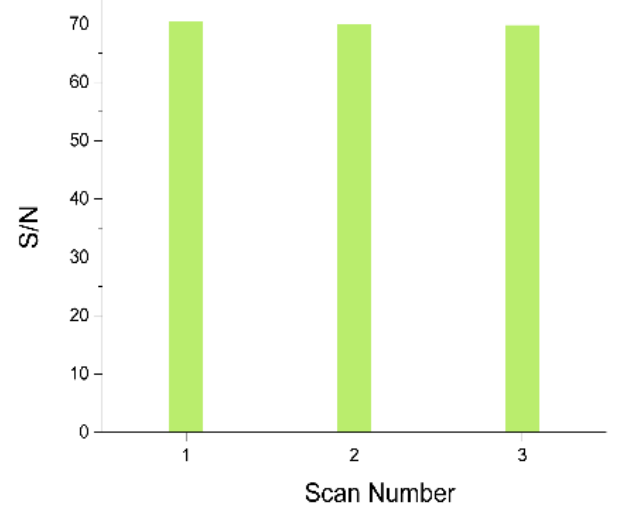

h)

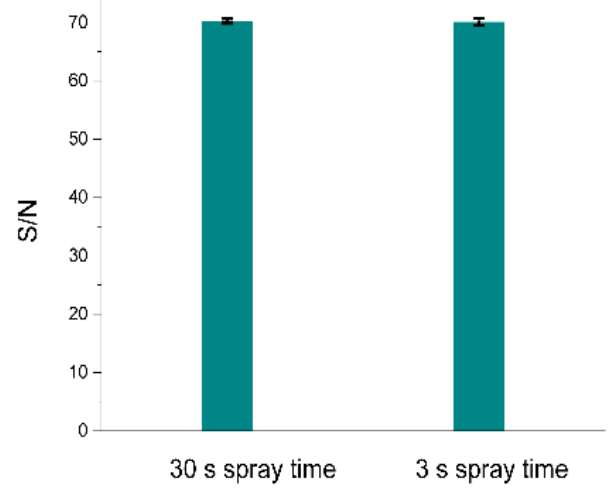


Figure S5 Comparison of MS signals with different spray time using $10 \mu \mathrm{M}$ metoprolol. a) and b) ion chronograms of a 30 s spray and a 3 s spray, respectively. c) and d) Relative intensity of each scan of a 30 s spray and a 3 s spray, respectively. e) and f) S/N of each scan of a 30 s spray and a $3 \mathrm{~s}$ spray, respectively. g) and h) comparison of average relative intensity and $\mathrm{S} / \mathrm{N}$ of a $30 \mathrm{~s}$ spray and a 3 s spray, respectively. 
a)

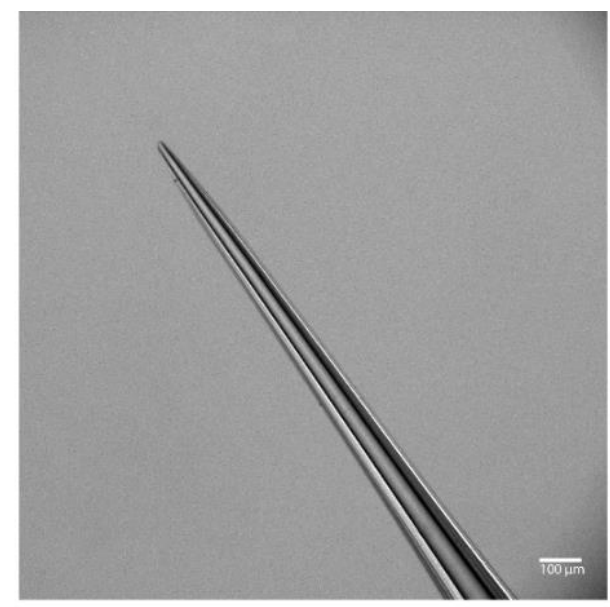

c)

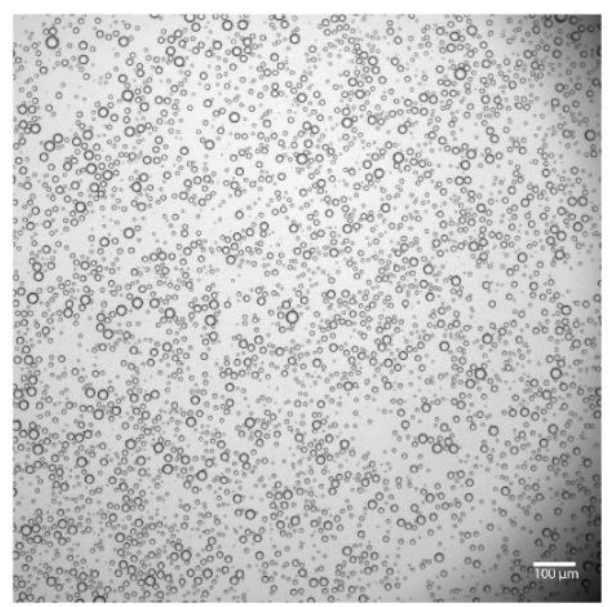

e)

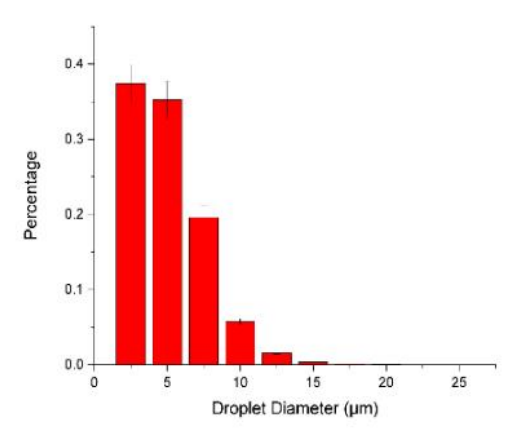

g)

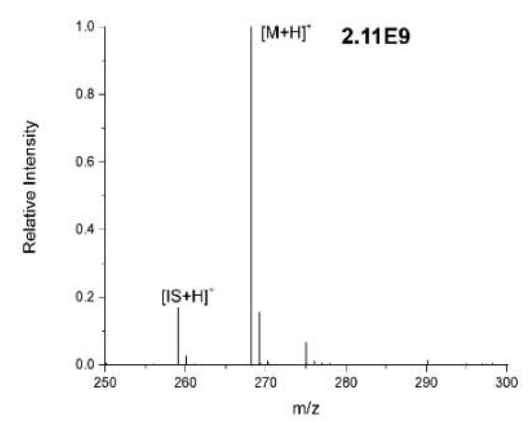

b)

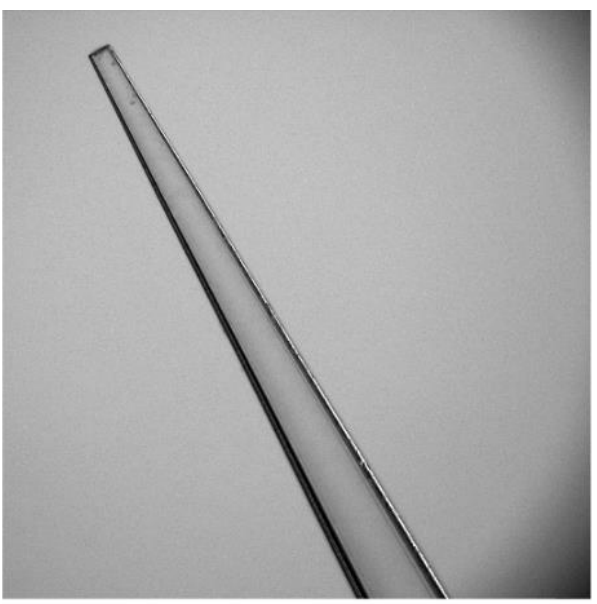

d)

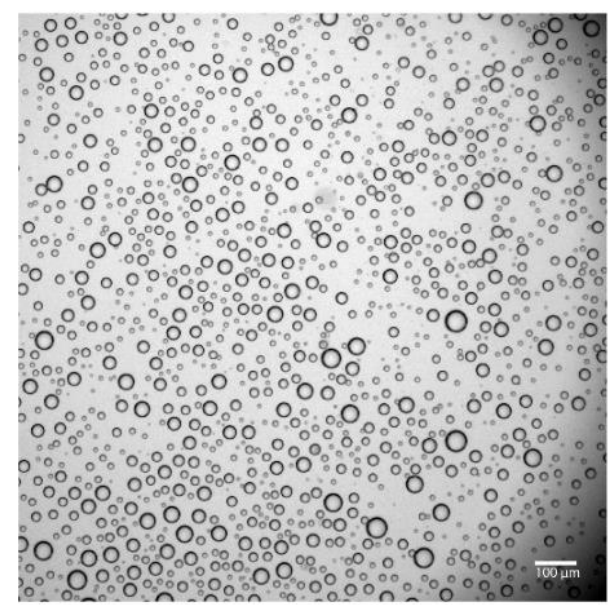

f)

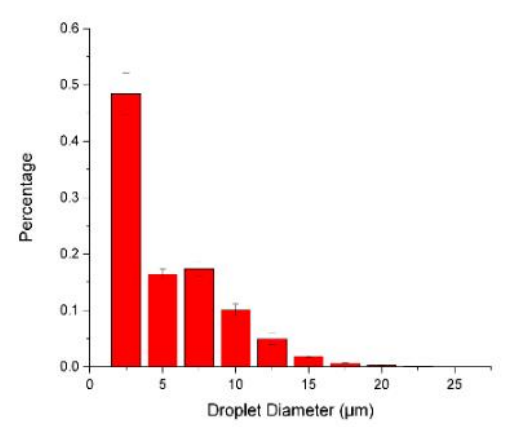

h)

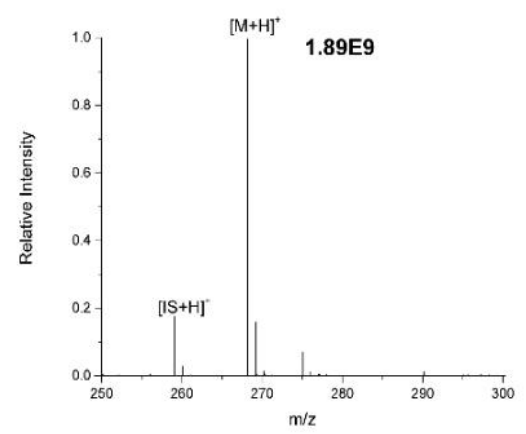


Figure $\mathrm{S} 6$ Comparison of capillaries with $15 \mu \mathrm{m}$ and $50 \mu \mathrm{m}$ tip size. a) and b) microscopy images of a $15 \mu \mathrm{m}$ tip and a $50 \mu \mathrm{m}$ tip, respectively. c) and d) microscopy images of droplets generated by a $15 \mu \mathrm{m}$ tip and a $50 \mu \mathrm{m}$ tip, respectively. e) and f) size distribution of droplets generated by a $15 \mu \mathrm{m}$ tip and a $50 \mu \mathrm{m}$ tip, respectively. g) and h) comparison of mass spectra of $10 \mu \mathrm{M}$ metoprolol generated by a $15 \mu \mathrm{m}$ tip and a $50 \mu \mathrm{m}$ tip, respectively. 


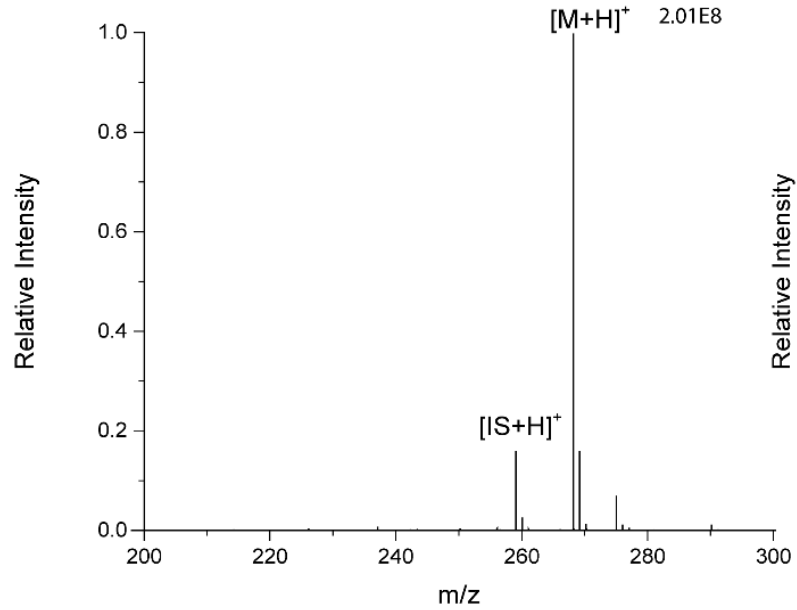

Pipette Tip Sealed with GLue

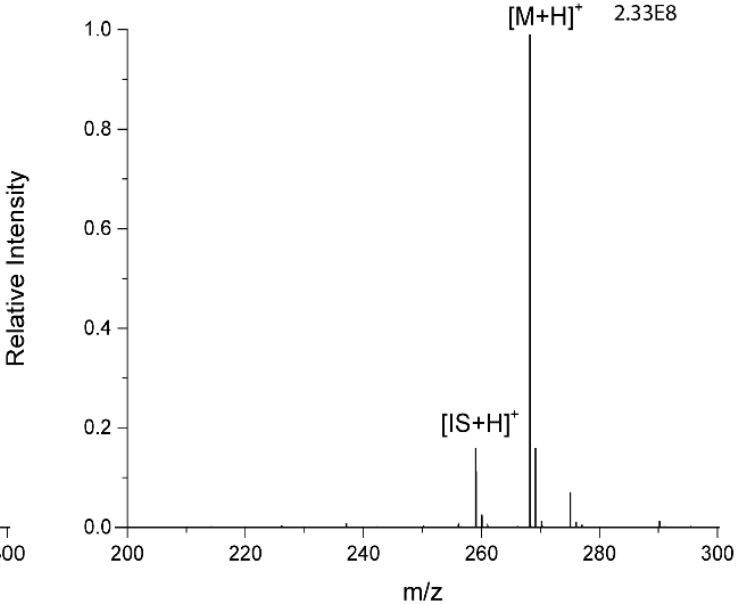

Low Volume Vial

Figure S7 Comparison of mass spectra $10 \mu \mathrm{M}$ metoprolol obtained with glue seal (left) and without glue (right). 


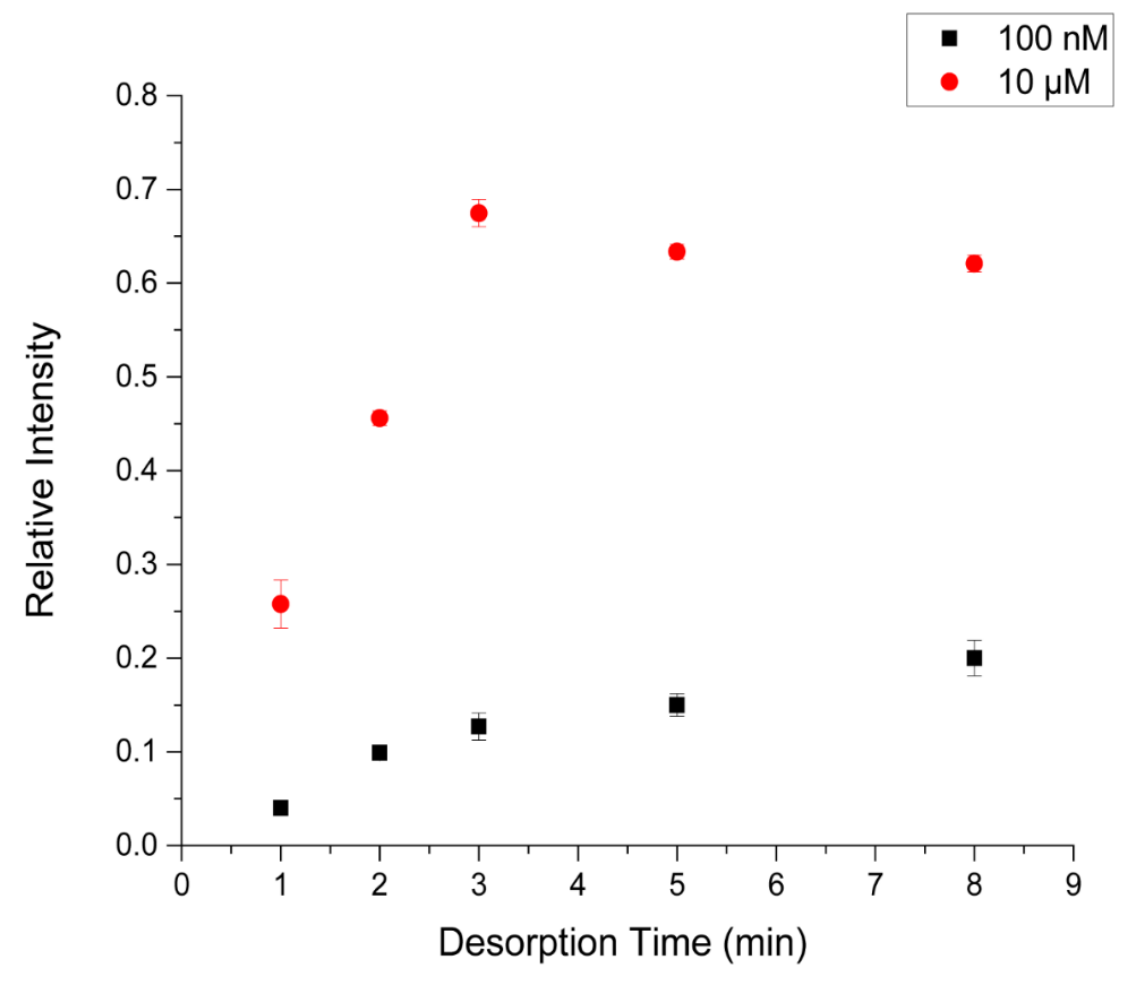

Figure S8 The relationship between the signal response and the desorption time with $500 \mu \mathrm{L}$ extraction volume, 24 min extraction time, and $6 \mu \mathrm{L}$ desorption volume for $100 \mathrm{nM}$ and $10 \mu \mathrm{M}$ metoprolol samples. 


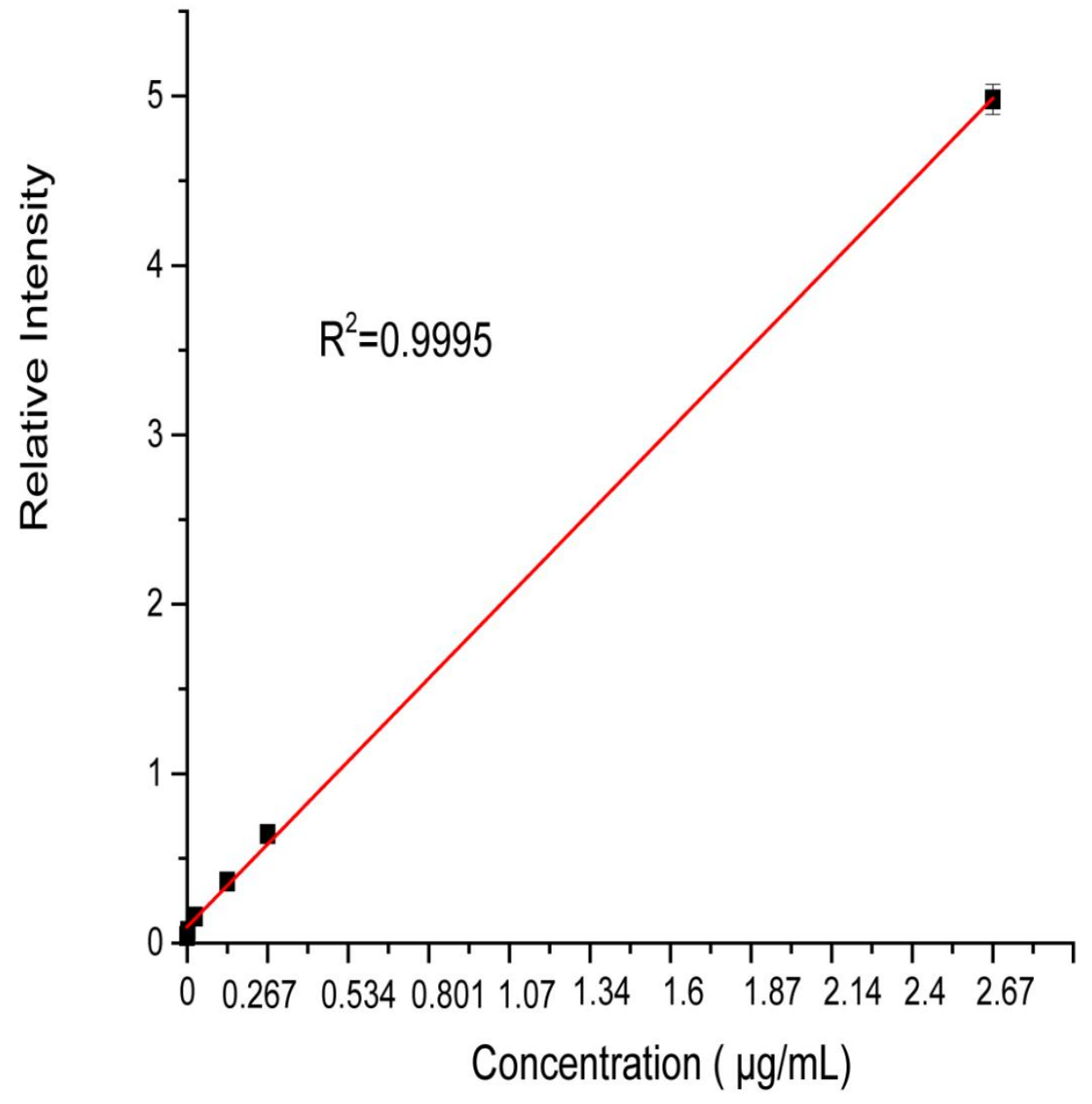

Figure S9: The calibration curve for metoprolol in serum samples obtained using SPME-cVSSIMS. 


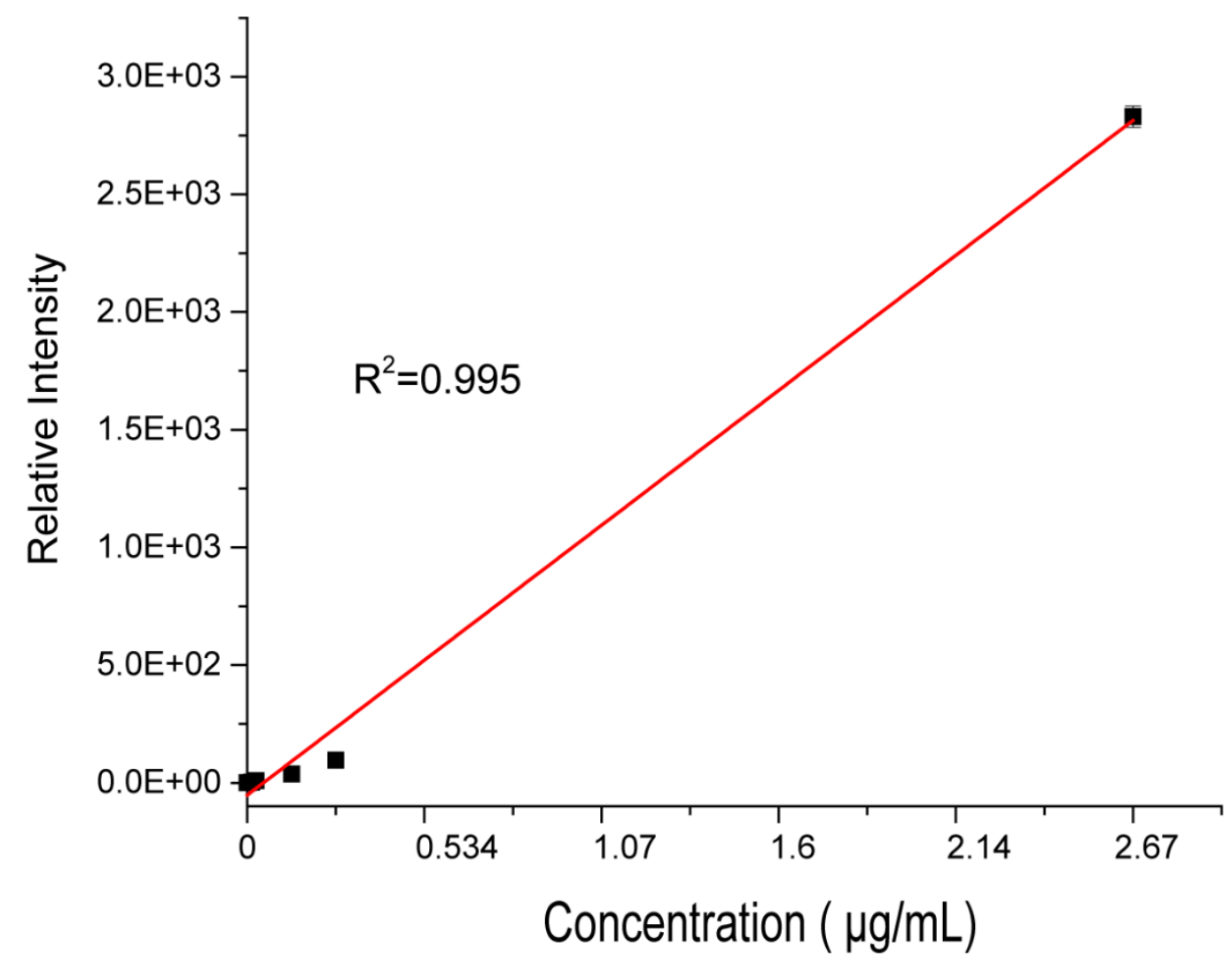

Figure S10: The calibration curve for metoprolol in serum samples obtained using SPME-nESIMS. 
a)

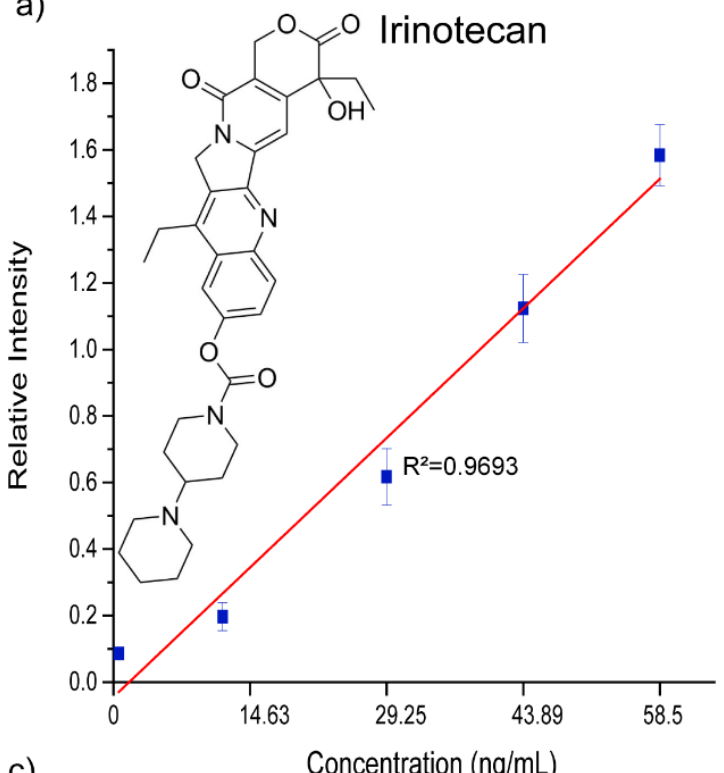

c)

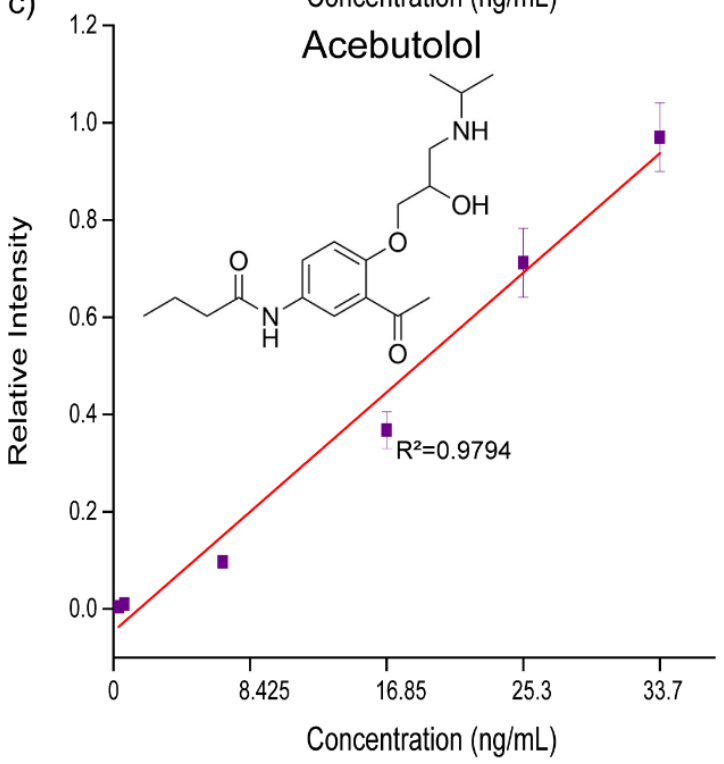

b)

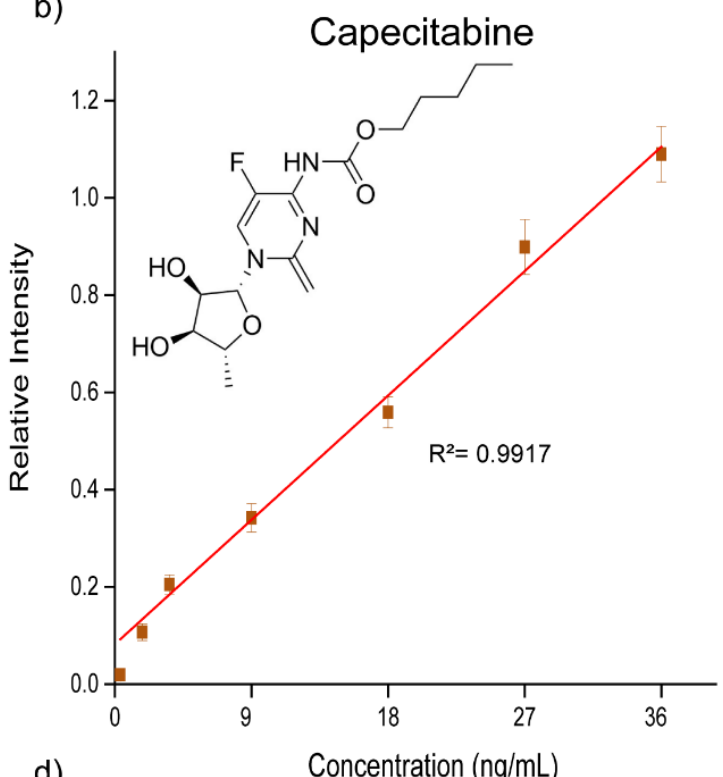

d)

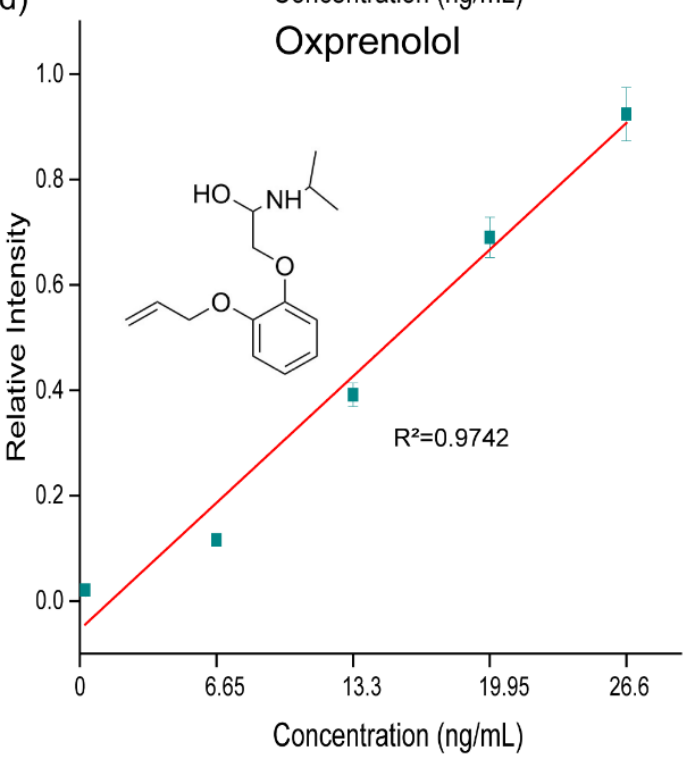

Figure S11: Calibration curves for 4 different drug compounds from serum samples. (a)-(d) irinotecan, capecitabine, acebutolol, and oxprenolol, respectively. 


\section{References:}

1. Lundborg, P., Steen, B.: Plasma levels and effect on heart rate and blood pressure of metoprolol after acute oral administration in 12 geriatric patients. Acta medica Scandinavica. 200, 397-402 (1976)

2. Abdel-Hamid, M.E., Phillips, O.A.: LC-MS/MS Determination of Carbamazepine, Pindolol, and Theophylline in Human Serum. Journal of Liquid Chromatography \& Related Technologies. 26, 1937-1957 (2003)

3. Satoh, T., Yasui, H., Muro, K.E.I., Komatsu, Y., Sameshima, S., Yamaguchi, K., Sugihara, K.: Pharmacokinetic Assessment of Irinotecan, SN-38, and SN-38-Glucuronide: A Substudy of the FIRIS Study. Anticancer Research. 33, 3845 (2013)

4. Reigner, B., Blesch, K., Weidekamm, E.: Clinical Pharmacokinetics of Capecitabine. Clinical pharmacokinetics. 40, 85-104 (2001)

5. Love, J.N.: Acebutolol overdose resulting in fatalities. The Journal of emergency medicine. 18, 341-344 (2000)

6. Bolli, P., Bühler, F.R., Raeder, E.A., Amann, F.W., Meier, M., Rogg, H., Burckhardt, D.: Lack of beta-adrenoreceptor hypersensitivity after abrupt withdrawal of long-term therapy with oxprenolol. Circulation. 64, 1130-1134 (1981) 